\title{
The influence of poisoning with patulin on activity of acid phosphatase, cathepsin B and $D$ in mice kidneys and livers
}

\author{
Andrzej Borzęcki ${ }^{1, A}{ }^{\oplus}$, Barbara Nieradko-Iwanicka ${ }^{2, D-F} \oplus$, Joanna Mikocka ${ }^{3, B-C \odot}$ \\ ${ }^{1}$ Chair and Department of Hygiene, Medical University, Lublin, Poland \\ ${ }^{2}$ Medical University, Lublin, Poland \\ 3 Provincial Unified Hospital, Swiętokrzyskie Cardiology Centre, Kielce, Poland \\ A - Research concept and design, B - Collection and/or assembly of data, C - Data analysis and interpretation, \\ $D$ - Writing the article, E-Critical revision of the article, $F$ - Final approval of article
}

\begin{abstract}
Borzęcki A, Nieradko-Iwanicka B, Mikocka J. The influence of poisoning with patulin on activity of acid phosphatase, cathepsin B and D in
\end{abstract} mice kidneys and livers. J Pre Clin Clin Res. 2020; 14(3): 94-97. 10.26444/jpccr/126833

\begin{abstract}
Introduction. Patulin is a mycotoxin produced by a variety of moulds, for instance, Aspergillus, Penicillium and Byssochlamys, and found most often in rotten apples. Previous studies showed toxic effects of patulin in the gastro-intestinal tract, impairment of kidney function, as well as neurotoxicity.

Objective. The aim of the study was to investigate whether intoxication with patulin affects the activity of acid phosphatase, cathepsin B and D in mice kidneys and livers.

Materials and method. Experiments were conducted on 36 female mice. Animals were divided into 6 groups of 6: 1 - control, 2 - received 0.1 LD50 patulin i.p. 28 days, 3 - saline i.p. once, 4 - patulin i.p. 0.1 LD50 once, 5 patulin i.p. 0.2 LD50 once, 6 patulin i.p. 0.5 LD50 once. 6 hours after patulin or saline administration, animals from groups 3, 4, 5, 6 were sacrificed. Kidneys and livers were obtained. Animals from groups 1 and 2 were sacrificed on day 29. Acid phosphatase activity was measured in the tissue supernatants with colorimetric method. Cathepsin B and D activities were determined with an ELISA-kit.

Results. The activities of acid phosphatase, cathepsin B and D in the kidneys and livers of mice exposed to patulin for 28 days was higher than in controls. A proportionate increase in acid phosphatase and cathepsin B activity in the kidneys and livers was observed for a single dose of the xenobiotic.

Conclusions. Acute and subacute poisoning with patulin negatively affects the functioning of lysosomes and induces an increase in the activity of lysosomal enzymes in mice livers and kidneys. Activities of acid phosphatase and selected cathepsins in the livers and kidneys are markers of cell damage due to patulin's toxicity.
\end{abstract}

\section{Key words}

hepatotoxicity, nephrotoxicity, Patulin

\section{INTRODUCTION}

Patulin is a mycotoxin produced by a variety of moulds, for instance, Aspergillus, Penicillium and Byssochlamys [1, 2], and found most often in rotten apples [3]. Patulin has been detected not only in apple juices, jam and ciders, but also in cherries, strawberries, plums, bananas, blueberries and grapes $[4,5,6]$. The World Health Organization recommends a maximum concentration of $50 \mu \mathrm{g} / \mathrm{L}$ of patulin in apple juice [7]. There are reports that patulin has also been detected in grains: barley, corn, wheat, and their products, as well as in shellfish [8]. Pasteurization or thermal denaturation do not destroy patulin, as the compound is heat-stable [9].

Patulin was previously used as an antibiotic against Grampositive and Gram-negative bacteria. It was recognized for use as anticancer compound and a drug to treat the common cold [9]. However after several reports about its' toxicity in 1950-1960, it is no longer used as a medicine [10].

Patulin exerts its toxicity through covalent binding to the sulfhydryl group of amino-acids [9].

Studies summarized by $\mathrm{Pal}$ et al. showed that patulin in

Address for correspondence: Barbara Nieradko-Iwanicka, Medical University of Lublin, Radziwiłłowska 11, 20-080 Lublin, Poland

E-mail: bnieradkoiwanicka@wp.pl

Received: 01.07.2020; accepted: 25.08.2020; first published: 07.09.2020 vivo damaged liver, kidneys, intestinal tissues and immune system in mammals. Several studies revealed mutagenic, teratogenic, DNA damaging and leading to the micronuclei formation effect of patulin in mammalian cells. Patulin reduces the expression of interleukin-23, interleukin-10, TGF- $\beta$, decreases interferon $\gamma$ production [9]. The mycotoxin at the dose of $0.1 \mathrm{mg} / \mathrm{kg}$ b.w. administered to male rats for 60 or 90 days caused haemorrhage, plasma cell hyperplasia, dilatation and fibrosis in the cortex, enlargement of the interstitial tissue between thymic lobules, thinning of the cortex, and blurring of the cortico-medullary demarcation in the thymus [9].

Acid phosphatase is an enzyme that hydrolysates orthophpsphate monoesters in $\mathrm{pH} 4-6$ during digestion. It can be further classified as a phosphomonoesterase. Acid phosphatase is stored in lysosomes and functions when these fuse with endosomes, which are acidified while they function; therefore, it has an acid $\mathrm{pH}$ optimum $[11,12,13]$. Acid phosphatase is present in the liver, kidneys, pancreas, placenta, bone marrow, bones, erythrocytes, granulocytes, platelets, serum, bile and urine. It regulates immune response, enables iron absorption, use of calcium and phosphorus by osteoblasts, helps in phagocytosis and mitosis [13].

Cathepsins are a group of endolysosomal proteases that regulate the mechanisms of innate and acquired 
immunity, including cell adhesion and migration, antigen processing and presentation, and resistance to numerous viral infections. Their abnormal activity can lead to many disease states, including the development of cancer.They regulate the mechanisms of immunity: cell adhesion and migration, resistance to viral infections, antigen processing and presentation. The name cathepsin comes from Greek kathepsein, meaning 'to digest' [14]. The cathepsins are: A-H, L, K, O S, V, W, X [15]. Some enzymes of this group are required for Toll-like receptor cleavage and for the formation of functional receptors which play a role in sensing viruses (especially nucleic acids). Cathepsins are able to stimulate or inhibit the secretion of cytokines that are involved in the regulation of antiviral immune response. Cathepsins are very important in the entry of filoviruses, retroviruses and reoviruses into the host cell. Cathepsins are necessary for some enveloped viruses for fusion with membranes of infected cells. The inhibition of cathepsins may result in a reduction of virus replication. Moreover, viruses utilize endocytosis or low $\mathrm{pH}$ within the endosome for their penetration into the cell, to disassembly of the viral capsid, and for productive viral replication [15].

Cathepsins B, C, F, H, L, K, O, S, V, W and X are cysteine proteases from the papain family and make up the largest and best known class of cathepsins. On the other hand, cathepsins A and $G$ belong to the serine proteases, and cathepsins D and $\mathrm{E}$ to the aspartate proteases.

Humans can be exposed to patulin via oral route chronically. Therefore, the question arises whether exposure to food contaminated with this mycotoxin could affect activity of lysosomal enzyme acid phosphatase and selected cathepsins in organs most important for metabolism and elimination of xenobiotics: liver and kidney.

\section{OBJECTIVE}

The aim of the study was to investigate whether acute and subacute intoxication of mice with patulin at the dose of 0.1-0.5 LD50 intraperitoneally (i.p.) affects the activity of acid phosphatase, cathepsin B and D in mice kidneys and livers.

\section{MATERIALS AND METHOD}

The study was approved by the Ethical Committee in Lublin (Decision No. 22/2013) and conducted according to Polish and European law regulations. The authors had been trained in the planning and performance of experiments on animals. The experiment was conducted in the Centre for Experimental Medicine at the Medical University in Lublin. The experiment was supported by Grant No. DS227/13 from the Medical University in Lublin.

Patulin was purchased from Sigma Aldrich Merck (Germany). Saline was purchased from Glenmark Pharmaceuticals (India) in $5 \mathrm{ml}$ ampules. According to Pubchem [16], LD50 for patulin administered intraperitoneally to mice (without data about their gender) is $5 \mathrm{mg} / \mathrm{kg}$ b.w. and $10 \mathrm{mg} / \mathrm{kg}$ if administered via subcutaneous injection. According to our previous experience with female mice we considered patulin's intraperitoneal LD50 for female mice to be $10 \mathrm{mg} / \mathrm{kg}$.

Experiments were conducted on 36 female Albino Swiss mice. Female mice were used because our experience indicated, that they were more sensitive to xenobiotics when compared to males. They were housed in standard laboratory conditions. Animals were randomly selected and divided into 6 groups of 6 mice each:

Group 1 - control group received saline i.p. for 28 subsequent days;

Group 2 - received patulin i.p. at the dose of $0.1 \mathrm{LD} 50$ (1mg/ $\mathrm{kg}$ b.w.) for 28 subsequent days;

Group 3 - received saline i.p. once;

Group 4 - received patulin i.p. at the dose of 0.1 LD50 once (1mg/kg b.w.);

Group 5 - received patulin i.p. at the dose of 0.2 LD50 once (2mg/kg b.w.);

Group 6 - received patulin i.p. at the dose of 0.5 LD50 once (5mg/kg b.w.).

Our previous experience showed that 6 hours after i.p. patulin administration, signs of its toxicity are best visible. Therefore, 6 hours after patulin or saline administration, animals from groups $3,4,5,6$, were sacrificed, their kidneys and livers immediately retained. Animals from groups 1 and 2 were sacrificed on day 29, and their kidneys and livers were also retained. The tissues were homogenized in phosphate buffered saline $0.5 \mathrm{mg}$ tissue $/ 2 \mathrm{~mL}$ of buffer purchased from Gibco (Scotland) and then centrifuged $\left(14,000 \times g, 4^{\circ} \mathrm{C}, 15\right.$ minutes) to yield the supernatant. Acid phosphatase activity was measured with a colorimetric method (wavelength 415nm) [17]. COBAS INEGRA 400 Plus analyzer manufactured by Roche (France) was used.

In the study, cathepsin B and D were chosen as the former belongs to the cysteine proteases from the papain family, and the latter is an example of aspartate proteases.

Cathepsin B and D activities were determined with an ELISA-kit purchased from EIAab Science Co., Ltd. (China) and used according to manufacturer's instructions. The kit allows for precise and specific determination of cathepsin $B$ activity within the range $0.78-50 \mathrm{ng} / \mathrm{mL}$, and cathepsin $\mathrm{D}$ within the range $78.0-5,000 \mathrm{pg} / \mathrm{mL}$. The measurement uses the sandwich ELISA method and was performed at wavelength $450 \pm 10 \mathrm{~nm}$. The minimum concentrations detected with this method were: cathepsin B $-0.78 \mathrm{ng} / \mathrm{mL}$ and for cathepsin D-78.0pg/mL. (Tab. 1), calculated per volume $(0.5 \mathrm{~g}$ tissue $/ 2 \mathrm{~mL})$ of supernatant used for enzyme determination.

The results were statistically analyzed. Shapiro - Wilk, U Mann - Whitney, ANOVA rang Kruskal - Wallis and Dunn's post hoc tests were used. $\mathrm{P}<0.05$ was considered statistically significant.

\section{RESULTS}

The activity of acid phosphatase in the kidneys and livers of mice exposed to patulin for 28 days was significantly higher than in controls (Tab. 1). The single dose proportionate increase in acid phosphatase activity in the kidneys and livers was observed after exposure to single dose of the xenobiotic. However, comparison of acid phosphatase activity in mice kidneys in groups 4,5,6 versus group 3 was considered not significant $(\mathrm{p}>0.05)$. Comparison of the acid phosphatase activity in mice livers in group $6 v s$ group 3 was statistically significant $(\mathrm{p}<0.05)$. Cathepsin B concentration was higher in the kidneys of mice after 28 days of intoxication with patulin, compared to controls, but the difference was not 
Table 1. Influence of poisoning with patulin on activity of acid phosphatase, cathepsin B and D in mice kidneys and livers

\begin{tabular}{|c|c|c|c|c|c|c|}
\hline Enzyme activity & $\begin{array}{l}\text { Group } 1 \text { - Control } \\
\text { group receiving } \\
\text { saline for } 28 \text { days }\end{array}$ & $\begin{array}{l}\text { Group } 2 \text { - receiving } \\
\text { patulin } 0.1 \text { LD50 } \\
\text { for } 28 \text { days }\end{array}$ & $\begin{array}{l}\text { Group } 3- \\
\text { receiving saline } \\
\text { i.p. once }\end{array}$ & $\begin{array}{l}\text { Group } 4 \text { - receiving } \\
\text { patulin } 0.1 \mathrm{LD} 50 \\
\text { once }\end{array}$ & $\begin{array}{c}\text { Group } 5 \text {-receiving } \\
\text { patulin } 0.2 \text { LD50 } \\
\text { once }\end{array}$ & $\begin{array}{c}\text { Group } 6 \text { - receiving } \\
\text { patulin } 0.5 \mathrm{LD} 50 \\
\text { once }\end{array}$ \\
\hline $\begin{array}{l}\text { Acid phosphatase activity in mice kidneys } \\
\text { (mean } \pm \text { SD) [U/L] }\end{array}$ & $14.37 \pm 10.483$ & $118.37 \pm 33.03^{*}$ & $76.22 \pm 37.523$ & $85.08 \pm 48.58$ & $96.65 \pm 15.33$ & $112.75 \pm 32.71$ \\
\hline $\begin{array}{l}\text { Acid phosphatase activity in mice livers } \\
(\text { mean } \pm \text { SD) }[\mathrm{U} / \mathrm{L}]\end{array}$ & $56.43 \pm 36.47$ & $125.13 \pm 31.28^{*}$ & $49.12 \pm 24.19$ & $59.67 \pm 40.79$ & $77.38 \pm 39.54$ & $99.57 \pm 45.97 \#$ \\
\hline $\begin{array}{l}\text { Cathepsin B in mice kidneys } \\
(\mathrm{mean} \pm \mathrm{SD})[\mathrm{ng} / \mathrm{mL}]\end{array}$ & $1.60 \pm 0.55$ & $5.73 \pm 0.75$ & $3.24 \pm 0.81$ & $4.41 \pm 1.46$ & $4.84 \pm 1.59$ & $5.54 \pm 0.52 \#$ \\
\hline $\begin{array}{l}\text { Cathepsin B in mice livers } \\
(\mathrm{mean} \pm \mathrm{SD})[\mathrm{ng} / \mathrm{mL}]\end{array}$ & $2.27 \pm 1.79$ & $2.79 \pm 1.01$ & $1.03 \pm 0.43$ & $1.84 \pm 0.57 \#$ & $2.62 \pm 1.45 \#$ & $3.52 \pm 1.29 \#$ \\
\hline $\begin{array}{l}\text { Cathepsin D in mice kidneys } \\
(\mathrm{mean} \pm \mathrm{SD})[\mathrm{pg} / \mathrm{mL}]\end{array}$ & $1292.5 \pm 500.5$ & $4657.5 \pm 997.5$ & $13330 \pm 975$ & $3332.5 \pm 1310$ & $5280 \pm 1020$ & $5280 \pm 1040 \#$ \\
\hline $\begin{array}{l}\text { Cathepsin D in mice livers } \\
(\mathrm{mean} \pm \mathrm{SD})[\mathrm{pg} / \mathrm{mL}]\end{array}$ & $5330 \pm 1080$ & $1056 \pm 1190$ & $5550 \pm 480$ & $5850 \pm 860$ & $6880 \pm 1970$ & $7670 \pm 1860 \#$ \\
\hline
\end{tabular}

statistically significant. Cathepsin B and D concentrations in acute poisoning with patulin were single dose proportionate and there was a statistically significant increase after exposure to the highest dose of the mycotoxin $v s$ control. Cathepsin B concentration in mice livers was significantly increased $(\mathrm{p}<0.05) v s$ control after exposure to each dose administered in an acute poisoning model. In the case of chronic poisoning, the increase was not significant $(\mathrm{p}>$ $0.05)$. Cathepsin D concentration in mice livers was elevated after 28 days of intoxication with patulin, but the increase was not statistically significant. In the case of exposure to a single dose of the mycotoxin, there was a dose proportionate increase in the level of cathepsin D in the livers, but only after the highest dose (0.5LD50) the increase was statistically significant compared to the control group (Tab. 1).

\section{DISCUSSION}

Patulin is produced by various fungi which can infect fruits and vegetables. It can accumulate in apples where patulin producing fungi cause blue rot [18]. Intoxication with this mycotoxin causes neurological, gastrointestinal, immunological adverse effects, hepatotoxicity and kidney damage in mammals [7].

The presnted study was intended to be a model of possible human exposure to patulin. Humans usually absorb patulin via the oral route, but in experiments on animals different routes of administration were tested. Administration via the oral route is usually associated with the first pass of the portal blood through the liver effect. Intravenous or i.p. administration requires lower doses of the xenobiotis and produces stronger toxic effects than by the oral route; therefore, in the current experiment, the intraperitoneal route of administration was chosen. In the study by Fuks-Holmber, patulin at the dose of $3 \mathrm{mg} / \mathrm{kg}$ b.w. per day in Tris-acetate buffer ( $\mathrm{pH}$ 5) was administered to rats orally. During the first 7 days, 3 of 7 rats treated with patulin died [19]. In order to avoid animal loss during the experiment, an alternative route of dosing was sought. Three different doses of patulin were administered, looking for the dose-effect correlation. As the oral dose of LD50 for patulin in rats is $27.79 \mathrm{mg} / \mathrm{kg}$ and in the cited publication a much lower dose was used, perhaps there was another reason for such a high mortality (possibly gastroenteritis, dehydration, hypersensitivity to vehiculum). In the current study, it was considered that i.p. administration guaranteed that the full dose of the xenobiotic was given to the animal, and had the opportunity to be absorbed into the bloodstream. The large surface of the peritoneum with its rich network of blood vessels allow the fast absorption of substances administered in this way. Group 2 in this experiment was a model of subacute poisoning with patulin, while groups 4, 5 and 6 - acute poisonoing. Acute, subacute and chronic exposures of humans to patulin are possible and depends on how often a person consumes apple juice and other contaminated foods and drinks.

In subchronic studies, patulin led to hyperaemia of the duodenal epithelium and kidney function impairment, agitation, convulsions, dyspnea, pulmonary congestion, oedema, ulceration and distention of the gastrointestinal tract [9]. The major retention sites of patulin are erythrocytes and the spleen, kidney, liver and lungs [9]. At cellular level, patulin produces plasma membrane disruption, inhibits protein synthesis, and $\mathrm{Na}^{+}$coupled amino acid transport, disrupts transcription and translation, inhibits DNA synthesis, inhibits interferon $\gamma$ producing T-helper type 1 cells [9]. This mycotoxin induces apoptosis either through the mitochondrial pathway or without the involvement of cytochrome p52. The interaction of patulin with sulfhydryl groups of macromolecules and subsequent generation of reactive oxygen species play major role in the apoptotic process after intoxication with the mycotoxin [20]. Glutathione is considered as the scavenger of patulin-induced toxicity as the mycotoxin exerts its toxicity by reacting with thiol groups [9]. Jayashree et al. showed that green tea leaves produced remarkable antioxidant and hepatoprotective effects in mice after poisoning with patulin [21].

Patulin interacts with cysteine-containing proteins. Many enzymes containing sulfhydryl group in their active site $\left(\mathrm{Na}^{+}-\mathrm{K}^{+}\right.$dependent ATPase, RNA polymerase, aminoacyltRNA synthetase, muscle aldolase) are inhibited by this mycotoxin [9]. Vinken et al. established deleterious effects of patulin on hepatic gap junctions [22].

Little information is available on the oral toxicity of patulin to primates. Garza et al., gave daily oral doses of patulin (5, $50,500 \mu \mathrm{g} / \mathrm{kg}$ b.w.) to pig-tail monkeys for 4 weeks, after which the monkeys exposed to the highest dose were given $5 \mathrm{mg}$ daily of the mycotoxin $/ \mathrm{kg}$ b.w. for another 2 weeks. The 
parameters determined after the experiment ended were: blood morphology, blood urea nitrogen, glucose, sodium and potassium, serum protein electrophoresis, serum glutamate oxalacetate transaminase, alkaline phosphatase, cholesterol and protein. No statistically significant changes were observed the in laboratory blood tests between the experimental groups of animals and controls, except for alkaline phosphatase, which decreased in the blood sera of animals exposed to the highest doses of patulin [23].

The liver transforms xenobiotics to metabolites. Exposure of mice to patulin causes an increase in the activity of serum alanine transaminase (ALT), aspartate transaminase (AST) and increased lipid peroxidation [9]. Primary cultures of adult human hepatocytes exposed to this mycotoxin showed reduced cell viability [9]. Since the liver, like other blood rich organs, is a possible toxic target of patulin, Lu et al. tested whether exposure to patulin can cause enhanced hepatotoxicity by using both cell culture (wild-type p53 cell lines and knockout p53 cell lines) and animal models. Results obtained in their study confirmed that the xenobiotic boosted reactive oxygen species generation both in vitro and in vivo. Patulin also inhibited catalase activity [24]. Results published by Jin et al. are in agreement with the above mentioned studies: patulin-induced hepatotoxicity develops in the mechanism of oxidative stress [25].

Kidneys are also sensitive to xenobiotics due to the high renal flow. Male albino mice receiving patulin orally at the dose of $152 \mathrm{ppb} / \mathrm{ml}$ for 6 weeks had increased urea, creatinine and uric acid in their blood sera [9]. The increase in the activity of acid phosphatase, catalase B and D in the liver and kidney of experimental mice after acute or subacute poisoning with patulin in the current experiment probably resulted from oxidative stress in the livers and kidneys, and accelerated the degradation processes. Damaged cells in the liver and kidney undergo cell death. Unfortunately, due to lack of means, no histopathological examinations of the livers or kidneys were carried out. However, it is suspect that accumulation of undigested molecules in the lysosomes increased the synthesis of acid phosphatase, which resulted in a high activity of the enzyme. Increased acid phosphatase activity is a marker of cell damage.

\section{CONCLUSIONS}

Acute and subacute poisoning with patulin negatively affects the functioning of lysosomes and induces an increase in the activity of lysosomal enzymes in mice livers and kidneys. Activities of acid phosphatase and selected cathepsins in the livers and kidneys are markers of cell damage due to patulin's toxicity.

\section{REFERENCES}

1. Alam S, Pal A, Kumar R, et al. EGFR-mediated Akt and MAPKs signal pathways play a crucial role in patulin-induced cell proliferation in primary murine keratinocytes via modulation of Cyclin D1 and COX-2 expression. Mol Carcinog. 2014; 53(12): 988-98.

2. Monteillier A, Allard PM, Gindro K, et al. Lung Cancer Chemopreventive Activity of Patulin Isolated from Penicillium vulpinum. Molecules. 2018; 23(3): 636-648.

3. Al-Hazmi MA. Patulin in apple juice and its risk assessments on albino mice. Toxicol Industrial Health. 2014; 30(6): 534-545.

4. Tsai WT, Lo YC, Wu MS, et al. Mycotoxin Patulin Suppresses Innate Immune Responses by Mitochondrial Dysfunction and p62/ Sequestosome-1-dependent Mitophagy. J Biol Chem. 2016; 291(37): 19299-311.

5. Piqué E, Vargas-Murga L, Gómez-Catalán J, et al. Occurrence of patulin in organic and conventional apple juice. Risk assessment. Recent Advances in Pharmaceutical Sciences III, 2013: 131-144. ISBN: 97881-7895-605-3 Eds: Muñoz-Torrero D, Cortés A, Mariño E. Transworld Research Network 37/661 (2), Fort P.O. Trivandrum-695 023 Kerala, India.

6. Zhong L, Carere J, Lu Z, et al. Patulin in Apples and Apple-Based Food Products: The Burdens and the Mitigation Strategies. Toxins (Basel). 2018; 10(11): 475-505.

7. Wouters FA, Speijers GJA. JECFA Monograph on Patulin. World Health Organization Food Additives. 2012 Series 35.

8. Alshannaq A, Yu JH. Occurrence, Toxicity, and Analysis of Major Mycotoxins in Food. Int J Environ Res Public Health. 2017; 14(6): 632-652.

9. Pal S, Singh N, Ansari KM. Toxicological effects of patulin mycotoxin on the mammalian system: an overview. Toxicol Res (Camb). 2017; 6(6): 764-771.

10. Medical Research Council. Clinical trial of patulin in the common cold. Lancet 1944; ii: 373-375.

11. Muniyan S, Chaturvedi NK, Dwyer JG, et al. Human prostatic acid phosphatase: structure, function and regulation. Int J Mol Sci. 2013; 14(5): 10438-64.

12. Cabukusta B, Neefjes J. Mechanisms of lysosomal positioning and movement. Traffic. 2018; 19(10): 761-769.

13. Vaithilingam A, Lai NY, Duong E, et al. A simple methodology to assess endolysosomal protease activity involved in antigen processing in human primary cells. BMC Cell Biol. 2013; 14: 35-46.

14. Turk V, Stoka V, Vasiljeva O, et al. Cysteine cathepsins: From structure, function and regulation to new frontiers. Biochim. Biophys. Acta. 2012; 1824: 68-88

15. Bossowska-Nowicka M, Toka F, Mielcarska M, et al. Cathepsins: innate immune proteases that regulate viral entry into host cells. Postępy Hig Med Dośw (online). 2018; 72: 253-263.

16.https://pubchem.ncbi.nlm.nih.gov

17. Wang J, Ni P, Chen C, et al. Colorimetric determination of the activity of alkaline phosphatase by exploiting the oxidase-like activity of palladium cube@CeO2 core-shell nanoparticles. Mikrochimica Acta. 2020; 187(2): 115.

18. Saleh I, Goktepe I. The characteristics, occurrence, and toxicological effects of patulin. Food and Chemical Toxicology. 2019; 129: 301-311.

19. Hazardous Substances Data Bank (HSDB).PATULIN. https://pubchem. ncbi.nlm.nih.gov/source/hsdb/3522(cited on June 12020 ).

20. de Melo FT, de Oliveira IM, Greggio S, Dacosta JC, Guecheva TN, Saffi J, Henriques JA, Rosa RM. DNA damage in organs of mice treated acutely with patulin, a known mycotoxin. Food Chem Toxicol.2012; 50: $3548-3555$.

21. Jayashree GV, Krupashree K, Rachitha P, et al. Patulin induced oxidative stress mediated apoptotic damage in mice, and its modulation by green tea leaves. J Clin Exp Hepatol. 2017; 7(2): 127-134.

22. Berthiller F, Crews C, Dall'Asta C, et al. Masked mycotoxins: a review. Mol Nutr Food Res. 2013; 57(1): 165-86.

23. Lu S, Liu S, et al. Combination of patulin and chlorpyrifos synergistically induces hepatotoxicity via inhibition of catalase activity and generation of reactive oxygen species. J Agric Food Chem. 2019.

24. Jin H, Yin S, Song X, et al. Hu H. P53 activation contributes to patulininduced nephrotoxicity via modulation of reactive oxygen species generation. Sci Rep. 2016; Article number 24455.

25. Rahman RMA, van Schaijik B, Brasch HD, et al. Expression of Cathepsins B, D, and G in WHO Grade I Meningioma. Front Surg. 2019;6:6. doi: 10.3389/fsurg.2019.00006. eCollection 2019. 